\title{
Landrace Maize Varieties Used as Phytoremediation of Contaminated Soil with 2,4-D + Picloram
}

\author{
Adriano Maltezo da Rocha \\ Universidade Estadual Paulista - UNESP, Campus de Jaboticabal - SP, Brazil \\ Oscar Mitsuo Yamashita \\ Universidade do Estado de Mato Grosso, Campus de Alta Floresta - MT, Brazil \\ Paulo Cesar Laurindo Silva \\ Instituto Federal de Mato Grosso - IFMT, Campus de Confresa - MT, Brazil \\ Marco Antonio Camillo de Carvalho \\ Universidade do Estado de Mato Grosso, Campus de Alta Floresta - MT, Brazil
}

Aureane Cristina Teixeira Ferreira Cândido

Universidade Federal do Oeste do Pará, Santarém - PA, Brazil

Amilton Ferreira da Silva

Universidade Federal de São João del Rey, São João del Rey - MG, Brazil

Delmonte Roboredo

Universidade do Estado de Mato Grosso, Campus de Alta Floresta - MT, Brazil

Hudson de Oliveira Rabelo

Universidade do Estado de Mato Grosso, Campus de Alta Floresta - MT, Brazil

Received: August 5, 2020

doi:10.5296/jas.v8i4.17480
Accepted: August 26, 2020

Published: Sep. 1, 2020

URL: https://doi.org/10.5296/jas.v8i4.17480 


\section{Abstract}

The use of herbicides such as 2,4-D + picloram in livestock areas can contaminate and hinder the use of the production system for subsequent crops of other crops. The objective of the research was to evaluate the ability of landrace maize varieties to reduce contamination of soil treated with 2,4-D + picloram, simulating existing conditions in the Amazon Biome. The experiment consisted of 6 phytoremediation treatments (4 landrace maize varieties, 1 hybrid maize cultivar and 1 control without cultivation), 2 herbicide conditions (with and without) and 3 evaluation periods (28,56 and 84 days). The soil was contaminated and the maize was subsequently cultivated under the herbicide conditions mentioned above. After each evaluation period, soil samples were collected, which were used to mount bioassays by growing cucumber (plants sensitive to the herbicide). Emergence, aerial dry mass and root dry mass were evaluated. All variables were affected by the herbicide residue. However, the reduction in herbicide persistence in each evaluation period was notable, resulting in the normal reestablishment of bioindicator seedlings, especially in the last evaluation at 84 days. The samples obtained in the soil cultivated with the varieties CR purple and CR white showed the best conditions for the development of cucumber, demonstrating the potential to be studied in phytoremediation programs.

Keywords: reduce contamination of soil. herbicide persistence. bioindicator plants

\section{Introduction}

In all extensive agroecosystems, both agricultural and livestock, it has been verified, throughout history, that production practices have inserted techniques and products aimed at increasing productive capacity, such as machines, implements, fertilizers and pesticides (Alencar et al., 2013).

Of all the pesticides used in agricultural and livestock practices, herbicides are the most consumed, reaching 52\% of the total of all products in this group used in Brazil (Ferreira and Vegro, 2015). This is reflected in pasture management practices, which generally require the use of herbicides considered persistent in the environment, with an emphasis on auxin mimics, such as 2,4-D, picloram, fluroxipyr, triclopyr and other formulations, which involve mixing of these and other active ingredients (D 'Antonino et al., 2009).

Picloram (4-amino 3,5,6 trichloro-2-pyridinecarboxylic acid) is an important herbicide, with the potential to control shrub dicot species in agroecosystems. It is a very efficient herbicide for the management of herbaceous and shrub weeds (very common in areas of livestock activity). 2,4-D (2,4 dichlorophenoxyacetic acid), on the other hand, is one of the main herbicides used in pastures, also acting in the control of dicotyledonous species (Rodrigues and Almeida, 2011). With these credentials, 2,4-D becomes an excellent alternative in the control of several invasive species in the cattle breeding system (Braga et al. 2013; Franceschi et al. 2017).

However, the herbicide molecule commercialized by the mixture between 2,4-D and picloram can become persistent in the environment, especially when it remains active in the soil, after application. This is due to picloram, which has been reported as a persistent molecule in the environment after long periods (Batistão et al., 2018). For this reason, information related to its 
persistence in agricultural systems needs to be taken into account (Franco et al. 2014).

There are plants that have the potential to extract or make certain herbicidal molecules unavailable, reducing their toxic potential in the environment, being called phytoremediation agents (Procópio et al., 2007). Thus, one of the premises of phytoremediation is the tolerance of the species to be cultivated in contaminated soil (Pires et al., 2003). Some research has already signaled the potential of the maize crop to tolerate the problems of contamination by herbicides. D'Antonino et al., (2009) state that maize has the capacity to be used in phytoremediation programs, so that it is possible to carry out the subsequent cultivation of plants of economic interest sensitive to the contaminating residue.

In addition to the characteristics of tolerance to the residue of auxinic herbicides, landrace maize varieties can have an important capacity to support the biotic and abiotic adversities that the environment provides, characterized by their high rusticity and tolerance to adverse conditions (Araújo and Nass, 2002; Silveira et al., 2015). These characteristics bring potentially interesting agricultural and environmental advantages, making maize varieties an important material for use in order to make the harmful effect of herbicide residues that remain in the soil after their use unavailable.

Therefore, the objective was to evaluate the capacity of landrace maize varieties in reducing the phytotoxic potential of 2,4-D + picloram, under Amazonian conditions.

\section{Material and Methods}

The research was carried out at the State University of Mato Grosso, Campus de Alta Floresta MT, Brazil, between the months of May and October 2017.

The experiment was conducted in a completely randomized design in a factorial scheme $(6 \times 3 \times 2)$, consisting of 6 phytoremediation agents (4 landrace maize varieties, 1 hybrid and 1 control exempt from maize cultivation), 2 herbicide conditions (with and without) and 3 evaluation times $(28,56$ and 84 days after emergence - DAE), with 4 repetitions for each treatment.

The soil used for the development of the research was classified as dystrophic Red-Yellow Latosol (Embrapa, 2013), collected from the forest area in the Amazon region, exempt from herbicide application, being removed from the 0.00-0.20m layer and subsequently, analysis was performed to the determination and quantification of the main nutrients and their granulometric characteristics (Table 1).

Based on these data, acidity and fertilization correction was carried out in order to satisfy the nutritional needs of the maize crop (Malavolta et al., 1981), for pot experiments. Finally, the corrected and fertilized soil was used to fill the experimental units, represented by pots with a capacity of $20 \mathrm{~L}$.

After filling in the experimental units, they were subjected to irrigation until saturation. Then, for 48 hours, the pots were kept without irrigation, allowing the excess water to drain. Subsequently, on the respective experimental units, the herbicide 2,4-D + picloram (Tordon ${ }^{\circledR}$ ) was applied at a concentration of $960 \mathrm{~g}$ and $256 \mathrm{~g}$ a.i. $\mathrm{ha}^{-1}$ respectively, corresponding to $2.0 \mathrm{~L}$ 
$\mathrm{ha}^{-1}$ of the product followed by the dose recommended by the manufacturer.

Table 1 Physical and chemical characterization of the dystrophic Red-Yellow Latosol used in the experiments before correction

Particle size analysis (\%)

\begin{tabular}{|c|c|c|c|c|c|c|c|c|c|c|}
\hline \multicolumn{2}{|l|}{ Silt } & \multicolumn{2}{|c|}{ Sand } & \multicolumn{2}{|c|}{ Clay } & \multicolumn{5}{|c|}{ Textural Classification } \\
\hline \multicolumn{2}{|l|}{36.1} & \multicolumn{2}{|c|}{5.70} & \multicolumn{2}{|c|}{57.9} & \multicolumn{5}{|c|}{ Sandy clay } \\
\hline \multicolumn{11}{|c|}{ Chemical analysis } \\
\hline pH & $\mathbf{P}$ & $\mathbf{K}^{+}$ & $\mathrm{Al}^{3+}$ & $\mathrm{Ca}^{2+}$ & $\mathrm{Mg}^{2+}$ & $\mathbf{H}+\mathbf{A l}$ & $\mathbf{T}$ & $\mathbf{V}$ & $\mathbf{m}$ & OM \\
\hline$\left(\mathrm{H}_{2} \mathrm{O}\right)$ & $\mathrm{mg}$ & & & & nol $_{c} d_{1}$ & & & & $\%$ & \\
\hline 5.70 & 1.5 & 94 & 0.10 & 1.02 & 0.38 & 2.23 & 3.90 & 42.40 & 5.20 & 2.00 \\
\hline
\end{tabular}

T: potential CTC.

The herbicide was applied with the aid of a backpack sprayer of constant pressure, maintained by pressurized $\mathrm{CO}_{2}$, provided with a bar with four spray tips APG 110.02 fan. The equipment was maintained at a constant pressure of $2.0 \mathrm{kgf} \mathrm{cm}^{-2}$, using water as a diluent and calibrating for application of $200 \mathrm{~L} \mathrm{ha}^{-1}$ of spray volume. After 48 hours of the application of the herbicide, in their respective concentrations, sowing the landrace maize varieties obtained from traditional farmers in the region were given the following denominations: CR black, CR white, CR yellow, CR purple and for comparison, a commercial hybrid maize cultivar (PAC Advanta) was used. Two plants were kept per pot.

The water supply to the experimental units occurred through a semi-automated irrigation system installed in a greenhouse, with two irrigations being carried out on the day. The irrigation system provided $840 \mathrm{~mm}$ throughout the experimental period, meeting the water needs of the crop and simulating the amount of rain that occurs in the Amazon region during this period.

After 28, 56 and 84 DAE of the plants (evaluation times), the plants were removed from each experimental unit and the soil of the pots was sieved. This soil was homogenized and 3 samples were subsequently collected. This soil was used to fill pots with a capacity of $600 \mathrm{~mL}$ to determine herbicide persistence. Cucumber (Cucumis sativus L.) was used as a bioindicator plant. 10 cucumber seeds were sown in each experimental unit. Previous germination test, indicated germination of $99 \%$ of the seeds of this species, the lot of which was purchased in local stores.

During the cultivation of cucumber, daily evaluations were carried out to determine the percentage of emergence and, at the end of 10 days after sowing, the percentage of emergence (\% E) was determined. And yet, in this last evaluation, considered as the end of the experimental period, destructive analyzes of the cucumber seedlings were carried out, 
evaluating the dry mass of the aerial part (DMAP) and root (DMRP).

For the dry mass of the aerial and root parts, the separated samples were placed to dry in a forced air circulation oven at $65^{\circ} \mathrm{C}$ until the constant weight was obtained, being measured on a precision analytical balance $(0.001 \mathrm{~g})$.

The results were subjected to analysis of variance and the means compared by the Tukey test at 5\% probability, using the SISVAR software (Ferreira, 2014).

\section{Results and Discussion}

In all the analyzed variables, there was significance, and for seedling emergence (\% $\mathrm{E})$, there was the effect of the herbicide factor alone. For dry mass of the aerial part, there was a double interaction between all factors (varieties $\mathrm{x}$ herbicide, varieties $\mathrm{x}$ evaluation times and herbicide $\mathrm{x}$ evaluation times), while for root dry mass there was interaction between the three factors studied (varieties $\mathrm{x}$ herbicide $\mathrm{x}$ evaluation times).

In the presence of the herbicide, the emergence of cucumber seedlings showed a visible reduction, demonstrating that the residues of the herbicide caused a negative change in the ability of the seeds to hydrate, germinate and emerge (Figure 2). Similar information was also reported by Nascimento \& Yamashita (2009) who, evaluating the effects of increasing doses of 2,4-D + picloram, found decreases in the emergence of the same species.

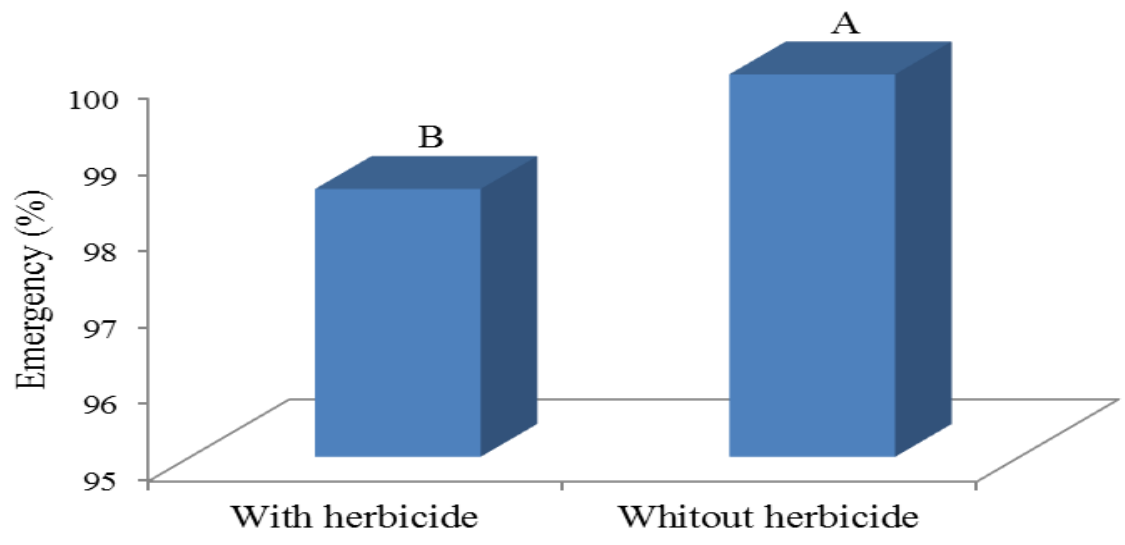

Figure 2 Emergence of cucumber seedlings grown in soil contaminated with 2,4-D + picloram at different times of evaluation

The residue of this herbicide can cause damage to sensitive species, causing a drastic reduction in their emergence. The effects on the early development of sensitive plants (tomatoes, lettuce, cucumbers, cotton, grapes and tobacco) can be seen in very low doses (Mancuso et al., 2011; Franceschi et al., 2019).

Its phytotoxic action occurs due to the hormonal imbalance that it promotes in the cells, after its absorption in the germination process and the subsequent abnormal development of the tissues in development of the affected seedling (Ahrens, 1994). In addition, they can cause changes in the meristematic activities of cells and anomalies in the cell division of younger cells. All of these abnormalities alter the normal seedling growth process, causing the seedling to die 
(Franceschi et al., 2019). Several species have already been described whose germination and initial development have been compromised by the presence of this herbicide, such as Scenedesmus quadricauda (Wong, 2000), Ipomoea quamoclit (Yamashita et al., 2010) and Regnellidium diphyllum (Cassanego et al., 2010).

For dry mass of the aerial part of the cucumber seedlings, analyzing the interaction between varieties $\mathrm{x}$ herbicide, it was found that the lowest values were obtained from samples taken from the landrace maize varieties, but that the varieties CR black and CR yellow did not differ from the hybrid. However, the soil without maize cultivation allowed the largest accumulation of dry mass of the aerial part, differing from the others (Table 2).

Table 2 Breakdown of Herbicide $x$ Varieties of the variable aerial dry mass of Cucumis sativus L. seedlings grown in soil contaminated with 2,4-D + picloram herbicide collected after cultivation of different maize varieties

Aerial dry mass (g)

Varieties Doses

With Without

\begin{tabular}{|c|c|c|c|c|}
\hline Hybrid & 0.16908 & $\mathrm{Ba}$ & 0.15575 & $\mathrm{Bab}$ \\
\hline CR black & 0.15650 & $\mathrm{CBa}$ & 0.14716 & $\mathrm{Ba}$ \\
\hline CR yellow & 0.15775 & $\mathrm{CBa}$ & 0.14900 & $\mathrm{Ba}$ \\
\hline CR purple & 0.15216 & $\mathrm{Ca}$ & 0.16175 & $\mathrm{BAa}$ \\
\hline CR white & 0.14858 & $\mathrm{Ca}$ & 0.14850 & $\mathrm{Ba}$ \\
\hline Witness & 0.19658 & $\mathrm{Aa}$ & 0.16866 & $\mathrm{Ab}$ \\
\hline DMS line & 0.01181 & & & \\
\hline DMS column & 0.01729 & & & \\
\hline
\end{tabular}

Means followed by the same capital letter in the column and lower case in the line do not differ by Tukey's test at $5 \%$ significance.

Possibly, the effect of accumulation of dry matter in cucumber seedlings, especially when grown in samples extracted from hybrid material and from control without maize cultivation, does not necessarily present an advantage for the plant, as some auxinic herbicides can act as growth promoters and increasing the development of some variables such as 2,4-D and picloram (Kelley and Riechers, 2007). This promoting effect occurs, because in reduced doses of these herbicides, mainly 2,4-D, they can promote plant growth to a certain extent, because in small concentrations, there is absorption and its use as a growth hormone, promoting the development of vegetable. In this way, this action may reflect those herbicides which, by being able to act as a plant hormone, can act directly on cell division, and consequently, with the 
increase in concentrations and application rate, they tend to cause anomalies mainly in sensitive dicots (Marchi et al., 2008).

Some authors like Deuber (2003); Nascimento and Yamashita (2009) report that 2,4-D and picloram may present some symptoms such as epinasty, as well as thickening of the stem. This occurs due to the alteration in the composition of auxins responsible directly for the growth of the stem and root through the cellular elongation in the plants, causing the performance of the plants to be affected (Taiz and Zeiger, 2013).

When evaluating the interaction between varieties $\mathrm{x}$ seasons, it was found that, in soils collected in the first evaluation (28 DAE), there was great variation between the varieties studied, with higher values of dry mass of cucumber verified in soil from cultivation with hybrid, CR yellow and soil without maize cultivation, presenting values that were between $17.65 ; 11.12$ and $11.52 \%$ increase, respectively when compared to the sample taken from the soil cultivated by the CR black variety (Table 3). In the other evaluations, whose collections were carried out at 54 and $84 \mathrm{DAE}$, the substrate that did not receive maize was the one that promoted the least accentuated decrease in the production of dry cucumber mass.

Table 3 Evaluation times x Varieties of the variable aerial dry mass of Cucumis sativus L. seedlings cultivated in soil contaminated with herbicide collected after cultivation of different maize varieties in three evaluation times

Aerial dry mass (g)

Varieties

Evaluation times (DAE - Days after emergency)

\begin{tabular}{lclllll} 
& \multicolumn{2}{c}{ 28 DAE } & 56 DAE & \multicolumn{2}{c}{ 84 DAE } \\
\hline Hybrid & 0.20737 & $\mathrm{Aa}$ & 0.14200 & $\mathrm{Bb}$ & 0.13787 & $\mathrm{Bb}$ \\
CR black & 0.17712 & $\mathrm{BCa}$ & 0.14887 & $\mathrm{Bb}$ & 0.12950 & $\mathrm{Bc}$ \\
CR yellow & 0.19212 & $\mathrm{ABa}$ & 0.13912 & $\mathrm{Bb}$ & 0.12887 & $\mathrm{Bc}$ \\
CR purple & 0.18612 & $\mathrm{BCa}$ & 0.14637 & $\mathrm{Bb}$ & 0.13837 & $\mathrm{Bb}$ \\
CR white & 0.17075 & $\mathrm{Ca}$ & 0.14850 & $\mathrm{Bb}$ & 0.12637 & $\mathrm{Bc}$ \\
Witness & 0.19300 & $\mathrm{ABa}$ & 0.17500 & $\mathrm{Ab}$ & 0.17987 & $\mathrm{Aab}$ \\
\hline
\end{tabular}

DMS line

0.01735

DMS column

0.02118

Means followed by the same capital letter in the column and lower case in the line do not differ by Tukey's test at $5 \%$ significance.

This variation found within each season level shows us the variation in the presence of the herbicide residue and its activity 28 DAE. However, when 56 and 84 DAE passed, there was a 
decrease in the development of this variable, indicating that the tolerance capacity in contaminated soil was practically the same as that of all tested materials. On the other hand, the presence of the herbicide was still detected regardless of the time and the material evaluated.

Thus, regardless of the material tested as a phytoremediation agent, there was a marked decrease in the aerial part dry mass (DMAP) of the seedlings of 28 and 56 DAE, with a decrease of 32;16;28; 13 and 9\% of dry mass for hybrid materials, CR black, CR yellow, CR purple, CR white and control, respectively. However, in the last two seasons (56 and 84 DAE), differences were observed only for the materials CR black, CR yellow and CR white, which continued to show a significant decrease in this variable with values of 13,7 and $15 \%$, respectively. While the others showed, even with little decrease, statistical similarity between the last two seasons.

The greatest development of DMAP in the control treatment, may have been due to the presence in adequate quantities of the fertilizers provided in the fertilization for implantation of the experiment and the fact that the soil was not unavailable due to the absence of maize cultivation, in addition to the action of the herbicide that after the use of indicator species, the effect of the presence of the herbicide in the soil was observable. Thus, in the absence of the phytoremediation species, there was always a greater response to this variable.

These results corroborate with studies such as D'Antonino et al. (2009), who evaluated the use of different cultures in the phytoremediation of picloram, observed that after 150 days of the application of 2,4-D there was still the residue of the herbicide. In addition, Franco et al. (2014) and Silva et al. (2012) also observed the presence of picloram even in small quantities 300 days and 196 days after sowing Urochloa brizantha and Eleusine coracana, which was the remedy species in the field, respectively.

Evaluating the interaction of time factors within herbicide levels (Figure 3). In the first evaluation time (26 DAE) the presence of the herbicide provided greater accumulations of cucumber DMAP in soil with the presence of the herbicide. On the other hand, studies developed by D'Antonino et al. (2009) reported a reduction in the dry matter accumulation of maize plants grown in argisol with 2,4-D + picloram residues. D'Antonino et al. (2012) found that this same herbicide caused a reduction in the dry matter content of coffee plants, grown in a contaminated area.

This difference found in the variation in research on reduction (D'Antonino et al. 2009) and increase as observed in the mass of bionication plants as observed in the present research in the first growing season, can be explained by the action of auxinic herbicides, that the disturbances caused by the same occurs due to the quantity of the molecule available, therefore, 2,4-D and picloram when available to vegetables in low concentrations, induces an intense cell division and as a result a possible increase in length and in plant mass (Tu et al., 2001), while the presence in large concentrations acts in the opposite way, causing the harmful effect on the plant to be observed and paralyzing growth.

However, when evaluated the last two evaluation times (56 and 84 days), it was observed that 54 days after emergence there was a significant reduction in the air mass of the cucumber 
seedlings with a decrease of 25 and $15 \%$ of the samples with and without herbicide, respectively, however at that time there was no significant difference between presence and absence. However, the decrease observed in samples with herbicide was so expressive that in the last 84 DAE evaluation, the decrease in air mass of cucumber seedlings grown in soil with herbicide showed values of when compared to cultivation in soil without herbicide.

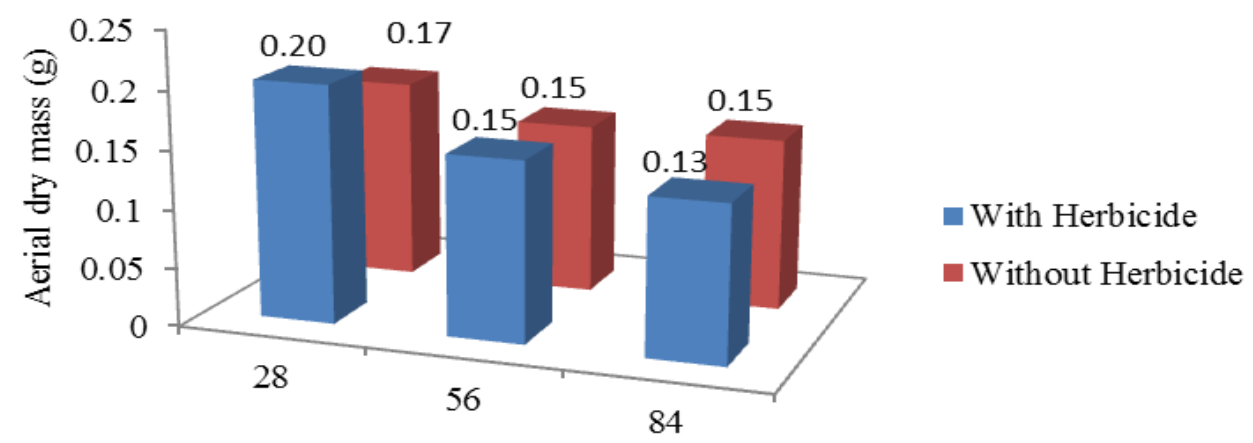

Day after emergency

Figure 3 Herbicide breakdown $\mathrm{x}$ evaluation times of the dry air mass variable of Cucumis sativus L. seedlings grown under different phytoremediation agents, herbicide dose and evaluation periods

In view of the reduction observed with the passing of the seasons, mainly of the cultivation in the presence of the herbicide, some researchers infer that the increase in the cultivation time of a phytoremediation plant can reduce the effect of the herbicide over time. Carmo et al. (2008) observed a reduction in the accumulation of dry matter of soybeans and tomatoes grown in an Oxisol contaminated with picloram. But they found that by cultivating Panicum maximum in this soil, there was a reduction in the phytotoxic effect, providing greater development of soy and tomatoes after 90 days, when the level of contamination did not exceed $80 \mathrm{~g} \mathrm{ha}^{-1}$ of picloram.

For DMRP, in the conditions of presence and absence of herbicide, it was found that the absence of the herbicide in the soil promoted the formation of greater root mass, except in the soil without previous cultivation of maize in the last evaluation (Table 4).

These results demonstrate that, in the treatments that had herbicide, in spite of the cultivation of maize, the phytoextraction of it was still not enough for the most significant reduction of its residues to the point of not causing damage to the bioindicator plant. However, the hybrid and the $\mathrm{CR}$ white showed, in this variable, that after 84 days, they can resume the development and accumulation of root mass, statistically equaling the cultivation of the bioindicator plant in uncontaminated soil. These results may be an indication of the possibility of phytoremediation of these varieties. 
Table 4 Sample Split x Herbicide x Evaluation times for root dry mass of Cucumis sativus L. seedlings grown under different phytoremediation agents, herbicide dose and evaluation times

\begin{tabular}{|c|c|c|c|c|c|}
\hline \multirow{3}{*}{$\begin{array}{c}\text { Varieties } \\
\text { CR yellow }\end{array}$} & \multirow{3}{*}{$\begin{array}{c}\text { Evaluation } \\
\text { time }\end{array}$} & \multicolumn{4}{|c|}{ Herbicide } \\
\hline & & \multicolumn{2}{|c|}{ With } & \multicolumn{2}{|c|}{ Without } \\
\hline & & 0.04750 & $\mathrm{ABb}$ & 0.08600 & $\mathrm{Aa}$ \\
\hline CR white & \multirow{5}{*}{28} & 0.03750 & $\mathrm{ABb}$ & 0.08325 & $\mathrm{Aa}$ \\
\hline Hybrid & & 0.03675 & $\mathrm{ABb}$ & 0.09250 & $\mathrm{Aa}$ \\
\hline CR black & & 0.03725 & $\mathrm{ABb}$ & 0.08950 & $\mathrm{Aa}$ \\
\hline CR purple & & 0.05475 & $\mathrm{Ab}$ & 0.09075 & $\mathrm{Aa}$ \\
\hline Witness & & 0.03600 & $\mathrm{Bb}$ & 0.08775 & $\mathrm{Aa}$ \\
\hline CR yellow & \multirow{6}{*}{56} & 0.07625 & $\mathrm{Ab}$ & 0.10100 & $\mathrm{BCa}$ \\
\hline CR white & & 0.07500 & $\mathrm{Aa}$ & 0.07850 & $\mathrm{Aa}$ \\
\hline Hybrid & & 0.07750 & $\mathrm{Ab}$ & 0.09100 & $\mathrm{ABa}$ \\
\hline CR black & & 0.07775 & $\mathrm{Ab}$ & 0.09775 & $\mathrm{Ba}$ \\
\hline CR purple & & 0.07700 & $\mathrm{Ab}$ & 0.09900 & $\mathrm{BCa}$ \\
\hline Witness & & 0.08075 & $\mathrm{Ab}$ & 0.11725 & $\mathrm{Ca}$ \\
\hline CR yellow & \multirow{6}{*}{84} & 0.07975 & $\mathrm{Cb}$ & 0.10150 & $\mathrm{Aa}$ \\
\hline CR white & & 0.09625 & $\mathrm{ABCa}$ & 0.10875 & $\mathrm{Aa}$ \\
\hline Hybrid & & 0.10000 & $\mathrm{ABa}$ & 0.10500 & $\mathrm{Aa}$ \\
\hline CR black & & 0.08825 & $\mathrm{BCb}$ & 0.10600 & $\mathrm{Aa}$ \\
\hline CR purple & & 0.08175 & $\mathrm{BCb}$ & 0.10400 & $\mathrm{Aa}$ \\
\hline Witness & & 0.11225 & $\mathrm{Aa}$ & 0.10600 & $\mathrm{Aa}$ \\
\hline DMS line & & 0.01274 & & & \\
\hline
\end{tabular}

Averages followed by the same lowercase letter on the line do not differ by Tukey's test at 5\% significance.

When comparing the varieties, in the first season of soil collection (28 DAE), the CR purple variety showed higher values for root dry mass, but it did not differ from the others, except for the soil that was not cultivated with maize. At $56 \mathrm{DAE}$, the contaminated soil promoted the production of cucumber roots that did not differ among themselves, regardless of the variety. Response variation between varieties was also verified at $84 \mathrm{DAE}$, in the presence of the herbicide in the soil.

The hormonal action of auxinic herbicides can influence differently, depending on the plant tested. The literature reports different effects on plants, but it is a fact that these products act as 
synthetic auxins, causing disorderly and uncontrolled growth in sensitive plants (Kelley \& Riechers, 2007; Oliveira Júnior, 2011; Rodrigues \& Almeida, 2011). Thus, its presence in the substrate and subsequent absorption causes disturbances in the nucleic acid metabolism, increasing the enzymatic activity and destroying the phloem. As a consequence, they can cause cell elongation, turgor and cell disruption, varying according to the sensitivity of each plant (Roman et al., 2007). The roots have their growth altered, losing their ability to absorb water and nutrients, causing rapid depletion of the plant's energy reserves and finally its death (Franceschi et al., 2019).

Throughout the evaluations, there was a greater root dry mass in the varieties whose substrate was contaminated with 2,4-D + picloram (Table 5). Thus, it is possible to infer that there was a reduction in the residual of this product over time due to the phytoremediation capacity of maize varieties. This phytoremediation is based on the selectivity, natural or developed, of these plants to the herbicide (Pires et al., 2003).

Table 5 Sample Split x Herbicide x Evaluation time for root dry mass of Cucumis sativus L. seedlings grown under different phytoremediation agents, herbicide dose and evaluation times

\begin{tabular}{cccccccc}
\hline \multirow{2}{*}{ Herbicide } & Varieties & \multicolumn{6}{c}{ Evaluation time (Days after emergency - DAE) } \\
\cline { 3 - 7 } & CR yellow & 0.04750 & $\mathrm{~b}$ & 0.07625 & $\mathrm{a}$ & 0.07975 & $\mathrm{a}$ \\
& CR white & 0.03750 & $\mathrm{c}$ & 0.07500 & $\mathrm{~b}$ & 0.09625 & $\mathrm{a}$ \\
\multirow{3}{*}{ With } & Hybrid & 0.03675 & $\mathrm{c}$ & 0.07750 & $\mathrm{~b}$ & 0.10000 & $\mathrm{a}$ \\
& CR black & 0.03725 & $\mathrm{~b}$ & 0.07775 & $\mathrm{a}$ & 0.08825 & $\mathrm{a}$ \\
& CR purple & 0.05475 & $\mathrm{~b}$ & 0.07700 & $\mathrm{a}$ & 0.08175 & $\mathrm{a}$ \\
& Witness & 0.03600 & $\mathrm{c}$ & 0.08075 & $\mathrm{~b}$ & 0.11225 & $\mathrm{a}$ \\
\hline \multirow{3}{*}{ Without } & CR yellow & 0.08600 & $\mathrm{~b}$ & 0.10150 & $\mathrm{a}$ & 0.10100 & $\mathrm{ab}$ \\
& CR white & 0.08325 & $\mathrm{~b}$ & 0.07850 & $\mathrm{~b}$ & 0.10875 & $\mathrm{a}$ \\
& Hybrid & 0.09250 & $\mathrm{a}$ & 0.09100 & $\mathrm{a}$ & 0.10500 & $\mathrm{a}$ \\
& CR black & 0.08950 & $\mathrm{~b}$ & 0.09775 & $\mathrm{ab}$ & 0.10600 & $\mathrm{a}$ \\
& CR purple & 0.09075 & $\mathrm{a}$ & 0.09900 & $\mathrm{a}$ & 0.10400 & $\mathrm{a}$ \\
& Witness & 0.08775 & $\mathrm{~b}$ & 0.11725 & $\mathrm{a}$ & 0.10600 & $\mathrm{a}$ \\
\hline
\end{tabular}

DMS line $\quad 0.01528$

Averages followed by the same lowercase letter on the line do not differ by Tukey's test at 5\% significance. 


\section{Conclusion}

All varieties showed potential for reducing the herbicide in the soil when the seasons were evaluated.

The varieties CR purple and CR white showed the best conditions for the development of cucumber seedlings, demonstrating that they are the potentials to be studied in phytoremediation programs.

\section{Acknowledgement}

Thanks to the Mato Grosso Research Support Foundation (FAPEMAT), for the scholarship granted to the first author. Thanks to LabFITO and LaSeM/CEPTAM/UNEMAT for the infrastructure to conducting the research. Thanks to Marcio Takeo Yamashita and Renata Yonaha Zocante for the technical support.

\section{References}

Alencar, G. V., Mendonça, E. S., Oliveira, T. S., Jucksch, I., \& Cecon, P. R. (2013). Percepção ambiental e uso do solo por agricultores de sistemas orgânicos e convencionais na Chapada da Ibiapaba, Ceará. Economia e Sociologia Rural, 51(2), 217-236. https://doi.org/10.1590/S0103-20032013000200001

Batistão, A. C., Yamashita, O. M., Silva, I. V., Araújo, C. F., \& Lavezo, A. (2018). Anatomical changes on the stem and leaves of Solanum lycopersicum caused by diferente concentrations of picloram $+2.4-\mathrm{D}$ in two different types of soil. Planta Daninha, 36, 1-12. https://doi.org/10.1590/s0100-83582018360100106

Braga, R. R., Costa, S. S. D., Ferreira, E. A., Santos, J. B., \& Silva, D. V. (2013). Atividade microbiana de solos contaminados com picloram e cultivados com Urochloa brizantha. Enciclopédia Biosfera, 9, 302-314.

Brasil, (2009). Ministério da Agricultura e Reforma Agrária. Regras para análise de sementes. Brasília: SNDA/DNDV/CLAV.

Carmo, M. L., Procopio, S. O., Pires, F. R., Cargnelutti Filho, A., Barroso, A. L. L., Silva, G. P., ... Pacheco, L. P. (2008). Plant selection for phytoremediation of soils contaminated with picloram. Planta Daninha, 26, 301-313. https://doi.org/10.1590/S0100-83582008000200006

Cassanego, M. B. B., Droste, A., \& Windischi, P. G. (2010). Effects of 2.4-D on the germination of megaspores and initial development of Regnellidium diphyllum Lindman (Monilophyta. Marsileaceae). Brazilian Journal of Biology, 2, 1-11. https://doi.org/10.1590/S1519-69842010005000014

D'Antonino, L., França, A. C., Silva, A. A., Ferreira, L. R., \& Silva, G. R. (2012). Development of coffee plants in soils with picloram residues. Planta Daninha, 30, 193-200. https://doi.org/10.1590/S0100-83582012000100022

D'Antonino, L., Silva, A. A., Ferreira, L. R., Cecon, P. R., Quirino, A. L. S., \& Freitas, L. H. L. (2009). Effects of cultures on the persistence of auxinic herbicides in soil. Planta Daninha, 
27(2), 371-378. https://doi.org/10.1590/S0100-83582009000200021

Deuber, R. (2003). Mecanismos de ação dos herbicidas. In: Deuber. R. Ciência das plantas infestantes: fundamentos. 2.ed. Jaboticabal: Funep.

Embrapa. (2013). Sistema Brasileiro de Classificação de Solos. 3. ed. Brasília: Embrapa; 2013.

Ferreira, C. R. R. P. T., \& Vegro. C. L. R. (2015). Defensivos Agrícolas: em 2014. faturamento do segmento foi o destaque. Análises e Indicadores do Agronegócio, 10, 1-6.

Ferreira, D. F. (2014). Sisvar: a Guide for its Bootstrap procedures in multiple comparisons. Ciência e Agrotecnologia, 38,109-112. https://doi.org/10.1590/S1413-70542014000200001

Franceschi, M., Arantes, S. A. C. M., Andrade, E. A., Rocha, A. M., Arantes, K. R., \& Yamashita, O. M. (2019). Liming on picloram leaching in dystrophic Red Yellow Latosol. Revista Brasileira de Engenharia Agrícola e Ambiental, 23(2), 103-108. http://dx.doi.org/10.1590/1807-1929/agriambi.v23n2p103-108

Franceschi, M., Yamashita, O. M., Arantes, S. A. C. M., \& Andrade, S. P. (2017). Behavior of 2.4-D + picloram Latosol Red-Yellow. Revista Brasileira de Herbicidas, 16(3), 238-245. https://doi.org/10.7824/rbh.v16i3.524

Franco, M. H. R. (2014). Phytoremediation of soils contaminated with picloram by Urochloa brizantha. Pesquisa Agropecuária Tropical, 44, 460-467. https://doi.org/10.1590/S1983-40632014000400003

Kelley, K. B., \& Riechers, D. E. (2007). Recent developments in auxin biology and new opportunities for auxinic herbicide research. Pesticide Biochemistry and Physiology, 89, 1-11. https://doi.org/10.1016/j.pestbp.2007.04.002

Malavolta, E. (1981). Manual de Química Agrícola: Adubos e Adubação. São Paulo: Agronômica Ceres.

Mancuso, M. A. C., Negrisoli, E., \& Perim, L. (2011). Residual effect of herbicides in soil ("Carryover"). Revista Brasileira de Herbicidas, 10(2), 151-164. https://doi.org/10.7824/rbh.v10i2.106

Nascimento, E. R., \& Yamashita, O. M. (2009). Initial development of vegetable crops cultivated in soils with 2.4-D + picloram resídues. Semina: Ciências Agrárias, 30, 47-54. http://dx.doi.org/10.5433/1679-0359.2009v30n1p47

Oliveira Júnior, R. S. (2011). Mecanismo de ação de herbicidas. In: Oliveira Júnior. R.S., Constantin, J. \& Inoue, M.H. Biologia e Manejo de Plantas Daninhas. Curitiba: Omnipax.

Oliveira Júnior, R. S. Constantin, J., Brandão Filho, J. U. T., Callegari, O., Pagliari, P. H., Cavalieri, S. D., ... Roso, A. C. (2007). Effect of sub-lethal dosages of 2.4-D on grape yield and crop susceptibility as a function of its development stage. Engenharia Agrícola, 27, 35-40. https://doi.org/10.1590/S0100-69162007000200006

Pires, F. R., Souza, C. M., Silva, A. A., Procópio, S. O., \& Ferreira, L. R. (2003). 
Phytoremediation of herbicide-polluted soils. Planta Daninha, 21(2), 335-341. https://doi.org/10.1590/S0100-83582003000200020

Procópio, S. O., Santos, J. B., Pires, F. R., Silva, A. A., Santos, E. A., \& Cargnelutti Filho, A. (2007). Development of bean plants in soil contaminated with trifloxysulfuron-sodium after Stizolobium aterrimum and Cannavalia ensiformis cultivation. Planta Daninha, 25(1), 87-96. https://doi.org/10.1590/S0100-83582007000100010

Rodrigues, B. N., \& Almeida, F. S. (2011). Guia de herbicidas. 7. ed. Londrina: IAPAR.

Roman, E., Vargas, L., Rizzardi, M.A., Hall, L., Beckie, H., \& Wolff, T. M. (2007). Como funcionam os herbicidas: da biologia à aplicação. Passo Fundo: Berthier.

Silva, A. A., \& Santos, J. (2007). Herbicidas: classificação e mecanismo de ação. Tópicos em manejo de plantas daninhas. Viçosa: Editora UFV.

Silva, L. O. C., Silva, A. A., Queiroz, M. E. L. R., Lima, C. F., Rocha, P. R. R., \& D'Antonino, L. (2012). Action of Eleusine coracana in the remediation of soils contaminated with picloram. Planta Daninha, 30(3), 627-632. https://doi.org/10.1590/S0100-83582012000300019

Taiz, L., \& Zeiger, E. (2013). Fisiologia vegetal. 5.ed. Porto Alegre:Artemed.

Thill, D. (2003). Growth regulator herbicides. In: Weller, S.C. Herbicide action course. West Lafayette: Purdue University.

Tu, M., Hurd, C., \& Randall, J.M. (2001). Weed control methods handbook: Tools and techniques for use in natural areas. The Nature Conservancy, 4(1), 533-540.

Wong, P. K. (2000). Effects of 2.4-D. glyphosate and paraquat on growth. photosynthesis and chlorophyll-a synthesis of Scenedesmus quadricauda Berb. Chemosphere, 41(1), 177-182. https://doi.org/10.1016/S0045-6535(99)00408-7

Yamashita, O. M., Borges, R. H., \& Carvalho, M. A. C. (2010). Effect of three herbicides on germination of Ipomoea quamoclit on moistened substract. Revista Científica Eletrônica de Agronomia, 17(1), 17-22.

\section{Copyright Disclaimer}

Copyright for this article is retained by the author(s), with first publication rights granted to the journal.

This is an open-access article distributed under the terms and conditions of the Creative Commons Attribution license (http://creativecommons.org/licenses/by/4.0/). 